\title{
KARAKTERISTIK KERUPUK IKAN BANDENG (Chanos chanos) DARI VARIASI JENIS PENGOLAHAN TEPUNG IKAN DAN PATI
}

\section{Characteristics of Milk Fish (Chanos chanos) Crackers with Varied Types of Fish Flour Processing and Starch}

\author{
Mulidati Mutya Khasanah, Rizky Muliani Dwi Ujianti*, Fafa Nurdyansyah, \\ dan M. Khoiron Ferdiansyah \\ Universitas PGRI Semarang, JI. Sidodadi Timur No. 24, Semarang, Indonesia \\ *Korespondensi Penulis: rizkymuliani@upgris.ac.id
}

Diterima: 21 November 2019; Direvisi: 2 Juli 2020; Disetujui: 3 Agustus 2020

\begin{abstract}
ABSTRAK
Kerupuk ikan bandeng (Chanos chanos) merupakan produk makanan kering yang terbuat dari campuran tepung ikan dengan tapioka atau sagu. Kerupuk ikan dapat dibuat dengan beberapa teknik pengolahan tepung ikan serta jenis pati. Kerupuk tidak akan mengembang dengan baik atau memiilki aroma yang disukai oleh konsumen, jika proses pembuatan tepung ikan atau komposisinya dengan pati tidak tepat. Oleh karena itu, penelitian ini dilakuan untuk mempelajari karakteristik fisiko-kimia dan organoleptik kerupuk ikan $C$. chanos yang dihasilkan dari variasi jenis proses pengolahan tepung ikan (rebus, kukus, dan presto) serta pati (tapioka dan sagu). Hasil penelitian menunjukkan bahwa kerupuk dengan komposisi 9:1 antara pati jenis tapioka dan tepung ikan hasil pengukusan adalah yang terbaik. Kerupuk ini memiliki kadar air 7,01\%; daya kembang 48,41\%; dan elastisitas 2,43 mm. Pengujian sensoris secara hedonik (skala 1-5) menunjukkan bahwa kerupuk matang dari komposisi tersebut dapat diterima dengan baik oleh panelis, berdasarkan parameter kerenyahan $(3,90)$, kerapuhan $(3,73)$, aroma $(3,06)$, rasa $(3,43)$, dan warna kecoklatan $(3,50)$.
\end{abstract}

KATA KUNCI : Chanos chanos, kerupuk, pati, pengolahan tepung ikan

\begin{abstract}
Milkfish cracker is a dry food product made from a mixture of milkfish meal with tapioca flour or sago flour. There are several options to choose the fish meal process and type of starches. Crackers will not expand properly and having the preferable consumers flavor, if it made from inappropriate fish meal processing and improper composition of starch. Thus, this research was conducted to study the physicochemical and sensory characteristics of fish crackers made from various types of

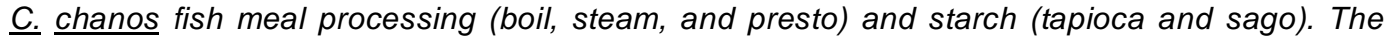
results revealed that the preferable crackers was made from 9:1 composition between tapioca starch and steamed fish flour. The crackers characterized with $7.01 \%$ moisture content, $48.41 \%$ linear expansion, and $2.43 \mathrm{~mm}$ elasticity. Sensory analysis (1-5 hedonic scale) showed the cracker made from described composition was preferable from several responses, which were crispiness (3.90), fragility (3.73), odor (3.06), taste (3.43), and brownish color (3.50)
\end{abstract}

KEYWORDS: Chanos chanos, Crackers, fish flour processing, starch

\section{PENDAHULUAN}

Kerupuk ikan merupakan produk makanan kering yang dibuat dari tepung, daging ikan, dan bahan tambahan lainnya. Ikan bandeng (Chanos chanos) adalah jenis ikan yang dapat digunakan dalam pembuatan kerupuk. C. chanos adalah ikan dengan kandungan nilai gizi yang sangat bermanfaat bagi tubuh manusia. Kandungan gizi daging $C$. chanos, seperti lemak total/asam lemak, protein/asam amino, dan mineral, dipengaruhi beberapa faktor, yaitu kelamin, umum, fase reproduksi, jenis pakan, serta lingkungan dan kualitas habitatnya (Aziz, Nematollahi, Siavash, \& Saei-Dehkordi, 2013; Hafiludin, 2015). Sebagai contoh, kadar protein dan lemak $C$. chanos dari perairan payau lebih tinggi dibandingkan perairan tawar (Hafiludin, 2015). 
Bahan baku ikan perlu diolah terlebih dahulu sebelum digunakan dalam pembuatan kerupuk, misalnya dengan cara penepungan. Bentuk tepung akan memudahkan dalam pencampuran dan memiliki rasa yang lebih khas. Tepung ikan yang berwarna coklat muda dapat diperoleh dengan cara pemasakan, penekanan, pengeringan, dan penggilingan (Assadad, Hakim, \& Widianto, 2015). Proses pemasakan pada suhu tinggi, seperti perebusan, pengukusan, dan presto, dapat meningkatkan palatabilias makanan. Ketiga teknik pemasakan ini akan mempertahankan cita rasa alami dan menghasilkan variasi komposisi tepung dengan bau, bentuk, serta tekstur yang khas (Nadeem, 2003; Saraswati, 2013).

Selain teknik pemasakan yang digunakan dalam penepungan ikan, pati merupakan komponen mayor yang penting dalam pembuatan kerupuk. Pati mengandung karbohidrat dalam jumlah tinggi (98\%) dan granulanya (97\%) memiliki daya kembang yang dibutuhkan kerupuk (Rizqia, 2016). Sagu dan tapioka adalah jenis pati yang kerap digunakan dalam membuat kerupuk. Jika proses pembuatan tepung ikan atau jenis pati yang dipilih tidak tepat, maka kerupuk tidak mengembang dengan baik atau memiliki aroma yang tidak disukai konsumen.

Oleh karena itu, tujuan penelitian ini adalah menelaah karakteristik fisiko-kimia dan sifat sensori kerupuk ikan dari variasi proses pengolahan tepung ikan dan pati. Karakteristik kimia fisika yang dipilih adalah kadar air, daya kembang, isoterm sorpsi air, dan elastisitas, berdasarkan penelitian yang dilakukan oleh Faridah, Pada, Yulastri, dan Yusuf (2008); Hayati, Abdullah, Ayob, dan Soekarto (2004); Sirpatrawan (2009); dan Zulfahmi, Swastawati, dan Romadhon (2014). Sementara itu, pengujian sensori (skala 1-5) secara deskriptif dilakukan berdasarkan SNI 01.23462006 (BSN, 2006) terhadap kerupuk ikan matang.

\section{BAHAN DAN METODE}

\section{Bahan}

Bahan baku yang digunakan untuk pembuatan tepung ikan adalah ikan Bandeng segar yang diperoleh dari Desa Wonorejo, Kecamatan Kaliwungu, Kendal, Jawa Tengah. Ikan diambil pada ukuran $23-25 \mathrm{~cm}$ dan berat per ekor 230-250 gram. Ikan dikemas dalam boks yang berisi es kristal untuk preservasi selama transportasi ke laboratorium. Bahan yang digunakan dalam pembuatan kerupuk adalah pati tapioka (Rose Brand), pati sagu (Merapi), garam (Kapal), ketumbar, air, dan bawang putih. Sementara itu, bahan kimiawi yang digunakan untuk analisis adalah $\mathrm{KCl}$ (Merck), $\mathrm{NaOH}$ (Merck), $\mathrm{MgCl}_{2}$ (Merck), $\mathrm{NaCl}$ (Merck), $\mathrm{K}_{2} \mathrm{CO}_{3}$ (Merck), $\mathrm{BaCl}_{2}$ (Merck), dan $\mathrm{NaNO}_{2}$ (Merck).

\section{Metode}

Penelitian dibagi menjadi dua tahap. Tahap pertama adalah pembuatan tepung ikan dengan variasi proses pengolahan (pengukusan, perebusan, dan presto), sementara tahap kedua adalah pembuatan kerupuk ikan (formulasi dengan tapioka atau sagu). Pembuatan kerupuk ikan menggunakan Rancangan Acak Lengkap (RAL) faktorial dengan 2 faktor perlakuan serta 2 kontrol, yaitu kerupuk yang hanya menggunakan $100 \%$ tapioka dan $100 \%$ sagu. Setiap perlakuan dilakukan dengan 3 ulangan.

\section{Pembuatan tepung ikan}

Proses pengolahan tepung ikan adalah modifikasi dari Susanto dan Nurhikmat (2008). Pada tahap awal, daging ikan dipisahkan dari sisik, jeroan, ekor, dan kepala, kemudian dicuci sampai bersih. Proses selanjutnya adalah pemasakan (30 menit pengukusan, perebusan, atau 15 menit presto). Daging dan duri ikan kemudian dihancurkan dalam blender kering (Sharp), lalu dikeringkan dengan cabinet dryer (UD rekayasa wangdi) selama 24 jam pada suhu $55^{\circ} \mathrm{C}$. Hasil pengeringan ini dihancurkan lebih lanjut dengan blender dan dilewatkan dalam saringan 60 mesh untuk menghasilkan tepung ikan. Perlakuan kontrol dibuat dari ikan segar yang langsung ditepungkan tanpa melalui proses pengolahan terlebih dahulu.

\section{Pembuatan kerupuk ikan}

Proses pembuatan kerupuk merupakan modifikasi dari penelitian Zulfahmi et al.,(2014). Pembuatan kerupuk ikan dimulai dengan mencampurkan semua bahan, seperti tepung ikan, pati, dan bumbu-bumbu yang sudah dihaluskan sebelumnya, kemudian adonan diaduk sampai kalis. Formulasi dilakukan dengan penambahan 10 gram tepung ikan ke 90 gram pati (tapioka atau sagu). Adonan yang sudah kalis lalu dibentuk, direbus (15 menit), ditiriskan, dan didinginkan selama 24 jam. Kerupuk yang sudah mengeras selanjutnya diiris dengan ketebalan $\pm 1-3$ $\mathrm{mm}$ dan dikeringkan dalam alat cabinet dryer selama 24 jam dengan suhu $55^{\circ} \mathrm{C}$. Proses memasak kerupuk adalah penggorengan pada suhu $180^{\circ} \mathrm{C}$ selama 20 detik.

\section{Uji karakteristik Fisio-kimia}

Karakteristik fisio-kimia kerupuk yang diamati adalah kadar air, daya kembang, isoterm sorpsi, dan elastisitas, berdasarkan metode AOAC (2012); Faridah et al., (2008); Hayati et al., (2004); dan Sirpatrawan (2009). Daya kembang kerupuk diperoleh dengan membandingkan luas (panjang $x$ lebar) kerupuk sebelum dan sesudah digoreng. Sementara 
itu, profil tekstur dianalisis menggunakan instrumentasi texture analyzer (Brookfield).

\section{Uji sensori}

Pengujian dilakukan secara deskriptif (skala 1-5) terhadap kerupuk ikan matang dengan 30 orang panelis menggunakan metode Yuliani, Marwati, Wardana, Emmawati, dan Candra (2018). Pengujian ini meliputi kerenyahan, rasa, aroma, kecoklatan, dan kerapuhan.

\section{Analisis data}

ANOVA dan uji lanjut Duncan dipergunakan dalam analisis statistik. Perangkat lunak yang digunakan dalam uji ini adalah SPSS 21.

\section{HASIL DAN PEMBAHASAN}

\section{Karakteristik Fisiko-kimia}

Pengujian fisiko-kimia menunjukkan kadar air kerupuk ikan mentah yang tidak berbeda signifikan $(p>0,05)$ antara berbagai jenis pengolahan tepung ikan, sagu, dan tapioka (Tabel 1). Perbedaan yang signifikan $(p<0,05)$ terdapat pada kerupuk dari tepung ikan yang tidak diolah. Kadar air dari tepung tanpa pengolahan (pada penambahan tapioka maupun sagu) secara signifikan $(p<0,05)$ lebih tinggi dari perlakuan lainnya.
Daya kembang dan elastisitas kerupuk secara umum hampir selaras $(p>0,05)$. Perbedaan yang signifikan $(p<0,05)$ adalah pada daya kembang kerupuk kontrol (sagu atau tapioka) dan elastisitas kerupuk A1B1. Sementara itu, pengujian isoterm sorpsi air memperlihatkan bahwa kerupuk yang ditambah sagu lebih mudah menyerap air dibandingkan tapioka (Gambar 1).

Kadar air kerupuk ikan yang diuji sudah memenuhi standar mutu SNI 2713-1-2009, yaitu maksimal 12\% (BSN, 2009). Kadar air dapat menjadi penentu kualitas kerupuk mentah maupun matang. Kadar air yang tinggi dapat disebabkan oleh bahan tepung ikan tanpa pengolahan. Air dalam bahan yang kurang menguap saat proses pengeringan akan berpengaruh terhadap kualitas kerupuk. Selain itu, jenis pati juga berpengaruh terhadap kadar air. Tapioka mengandung amilopektin yang lebih banyak dari sagu. Struktur bercabang amilopektin akan menyulitkan penyerapan air. Kadar air dalam kerupuk juga berpengaruh terhadap kualitas kerupuk. Kadar air yang tinggi dapat menghambat proses pengembangan, sehingga menyebabkan kerupuk dengan tekstur lebih keras, kering, dan kurang renyah (Astuti, Suharyon, \& Fitria, 2016).

Daya kembang dan elastisitas kerupuk juga dipengaruhi oleh kandungan amilosa dan amilopektin dalam pati. Gelatinisasi granula amilopektin pati pada

Tabel 1. Karakteristik kimia fisika kerupuk ikan C. chanos dari tepung ikan hasil proses kukus (A1), presto (A2), rebus (A3), tanpa pengolahan (A4), yang ditambahkan dengan tepung pati tapioka (B1) dan sagu (B2), dengan kontrol kerupuk mentah tapioka (K1) dan sagu (K2)

Table 1. Physicochemical characteristics of milk fish (‥ chanos) crackers made from fish flour that processed with steam (A1), presto (A2), boil (A3), and without any process (A4), mixed by tapioca starch (B1) and sago (B2), with tapioca (K1) and sago (K2) as controls

\begin{tabular}{cccc}
\hline $\begin{array}{c}\text { Perlakuan/ } \\
\text { Treatment }\end{array}$ & $\begin{array}{c}\text { Kadar Air/ } \\
\text { Moisture } \\
(\%)\end{array}$ & $\begin{array}{c}\text { Daya kembang/ } \\
\text { Linear expansion } \\
(\%)\end{array}$ & $\begin{array}{c}\text { Elastisitas/ } \\
\text { Elasticity } \\
(\mathbf{m m})\end{array}$ \\
\hline A1B1 & $7.01 \pm 0.17^{\mathrm{ab}}$ & $48.41 \pm 2.39^{\mathrm{a}}$ & $2.43 \pm 2.01^{\mathrm{b}}$ \\
A2B1 & $7.13 \pm 0.49^{\mathrm{ab}}$ & $45.31 \pm 3.93^{\mathrm{a}}$ & $1.70 \pm 0.26^{\mathrm{ab}}$ \\
A3B1 & $7.31 \pm 0.23^{\mathrm{abc}}$ & $44.75 \pm 8.65^{\mathrm{a}}$ & $1.56 \pm 0.20^{\mathrm{ab}}$ \\
A4B1 & $7.79 \pm 0.02^{\mathrm{c}}$ & $44.65 \pm 3.81^{\mathrm{a}}$ & $0.80 \pm 0.10^{\mathrm{a}}$ \\
A1B2 & $7.04 \pm 0.11^{\mathrm{ab}}$ & $47.02 \pm 1.44^{\mathrm{a}}$ & $0.70 \pm 0.45^{\mathrm{a}}$ \\
A2B2 & $7.16 \pm 0.80^{\mathrm{ab}}$ & $45.10 \pm 5.21^{\mathrm{a}}$ & $0.53 \pm 0.35^{\mathrm{a}}$ \\
A3B2 & $7.41 \pm 0.59^{\mathrm{bc}}$ & $44.89 \pm 0.78^{\mathrm{a}}$ & $0.40 \pm 0.17^{\mathrm{a}}$ \\
A4B2 & $7.79 \pm 0.69^{\mathrm{c}}$ & $42.85 \pm 3.42^{\mathrm{a}}$ & $0.40 \pm 0.43^{\mathrm{a}}$ \\
K1 & $6.81 \pm 0.15^{\mathrm{a}}$ & $63.19 \pm 10.13^{\mathrm{b}}$ & $1.86 \pm 1.30^{\mathrm{ab}}$ \\
K2 & $6.81 \pm 0.15^{\mathrm{a}}$ & $58.83 \pm 5.94^{\mathrm{b}}$ & $0.33 \pm 0.15^{\mathrm{a}}$ \\
\hline
\end{tabular}

Keterangan/Note: Notasi $a, b$, dan $c$, yang menyatakan perbedaan signifikan $(p<0,05) / a, b$, and $c$ notations explain the significance difference $(p<0.05)$ 

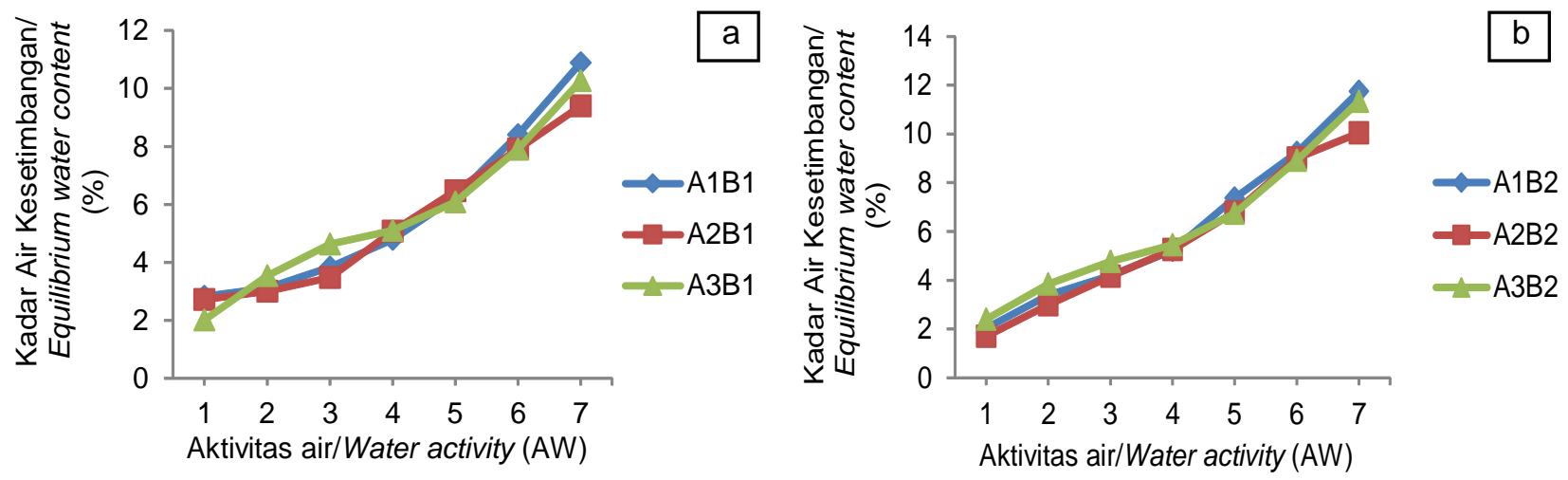

Gambar 1. Kurva isoterm sorpsi air dari kerupuk C. chanos dari tepung ikan hasil proses kukus (A1B1), presto (A2B1), rebus (A3B1) yang dicampur dengan pati tapioka (a) dan sagu (b)

Figure 1. The moisture sorption isotherms curve of $\underline{C}$. chanos cracker made from fish flour that processed with steam (A1B2), presto (A2B2), and boil (A3B2), and mixed with tapioca (a) and sago (b)

proses pemanasan akan menentukan pengembangan dan elastisitas kerupuk (Anjar, Dwi, \& Dimas, 2013). Hal inilah yang menyebabkan kerupuk kontrol K1 dan K2 memiliki nilai daya kembang lebih tinggi. Sementara itu, elastisitas tinggi K1, K2, dan A1B1, dipengaruhi proses gelatinisasi amilosa dan amilopektin saat pemanasan. Pada jenis pati yang mengandung kadar amilosa lebih tinggi, kekuatan ikatan hidrogen dalam granula menjadi lebih tinggi, sehingga membutuhkan energi yang lebih besar untuk proses gelatinisasi dan menghasilkan kerupuk dengan tekstur lebih keras dan kurang mengembang. Selain itu, Damayanti, Wahyuni, dan Wena (2014) mengungkapkan bahwa elastisitas juga dipengaruhi kandungan gluten dalam pati dan air. Gluten dapat terbentuk jika gliadin berinteraksi dengan air, memberikan sifat lembut dan elastis, sehingga kandungan air akan sebanding dengan elastisitasnya.

Aktivitas air yang terdeteksi pada kurva isoterm sorpsi air memperlihatkan interaksi kerupuk dengan air di lingkungannya. Hal ini akan mempengaruhi kerenyahan kerupuk. Kerupuk yang ditambah tapioka lebih banyak mengandung pati. Kandungan pati akan berbanding terbalik dengan jumlah air yang diserap saat gelatinisasi, karena amilopektin dapat membuat pati lebih basah, lengket, dan sedikit menyerap air (Witono, Kumalaputri, \& Lukman, 2012). Kerupuk yang banyak menyerap uap air akan mengakibatkan kerenyahannya berkurang. Perubahan kekuatan mekanik (termasuk kerenyahan) dapat terjadi karena air mampu melarutkan dan melunakkan matriks pati pada sebagian bahan pangan (Nurhayati, 2007). Tingkat penyerapan air dalam kerupuk tergantung pada kondisi lingkungan. Lingkungan dengan kelembaban tinggi dapat mengakibatkan kerupuk menjadi lunak dan mudah menyerap air, sebagai reaksi untuk menuju kondisi keseimbangan (Rosiani, Basito, \& Widiowati, 2015). Berdasarkan data kimia fisika secara keseluruhan, maka kerupuk dengan perlakuan terbaik adalah A1B1.

\section{Karakteristik Sensori}

Pengujian sensori menunjukkan hasil deskriptif kerenyahan, kerapuhan, aroma, rasa, dan warna yang berbeda (Tabel 2). Kerenyahan kerupuk A1B1 dengan A4B1 berbeda secara signifikan $(p<0,05)$, sementara kerapuhan kerupuk pada kontrol (K1 dan K2) berbeda nyata $(p<0,05)$ terhadap perlakuan lainnya. Aroma kerupuk matang tiap perlakuan juga secara umum berbeda secara signifikan $(p<0,05)$. Selain itu, warna kerupuk yang paling berbeda $(p<0,05)$ adalah A1B1.

Kerenyahan kerupuk dipengaruhi oleh daya kembang. Proses pembentukan rongga-rongga udara terjadi saat penggorengan kerupuk (Kusumaningrum, 2009). Kerupuk yang organoleptik bernilai lebih tinggi memiliki tekstur renyah dengan sifat mudah pecah, mudah rapuh, dan hancur (Wahyuningtyas \& Atmaka, 2014). Menurut Anggit, Darmanto, dan Swastawati (2010), penentuan kerapuhan produk pangan secara subjektif dapat dipengaruhi oleh penampakan fisik, dari bentuk dan potongan produk. Perlakuan K1 dan K2 memiliki nilai berkisar empat, yang menunjukkan kerapuhan dan kerenyahan tinggi saat ditekan dengan tangan maupun dimakan.

Warna dan aroma kerupuk juga menjadi daya tarik yang dipertimbangkan konsumen. Peningkatan karakter dari kedua variabel ini akan muncul saat kerupuk menyerap minyak pada proses penggorengan (Nurchotimah, 2002). Seluruh warna kerupuk matang agak disukai panelis, terutama pada perlakuan yang 
Tabel 2. Karakteristik deskriptif organoleptik kerupuk ikan $C$. chanos matang dari tepung ikan hasil proses kukus (A1), presto (A2), rebus (A3), dan tanpa pengolahan (A4), yang ditambahkan dengan tepung pati tapioka (B1) dan sagu (B2), dengan kontrol kerupuk mentah tapioka (K1) dan sagu (K2), serta notasi a, b, dan c, yang menyatakan perbedaan signifikan $(p<0,05)$

Table 2. Descriptive organoleptic characteristics of milkfish ( $\underline{\text { C. chanos }}$ crackers made from fish flour that processed with steam (A1), presto (A2), boil (A3), and without any process (A4), mixed by tapioca starch (B1) and sago (B2), with tapioca (K1) and sago (K2) as controls, while $a, b$, and c notations, explain the significance difference $(p<0.05)$

\begin{tabular}{cccccc}
\hline \multirow{2}{*}{$\begin{array}{c}\text { Perlakuan/ } \\
\text { Treatments }\end{array}$} & \multicolumn{5}{c}{$\begin{array}{c}\text { Ogranoleptik deskriptif (skala 1-5)/ } \\
\text { Descriptive organoleptic (1-5 scale) }\end{array}$} \\
\cline { 2 - 6 } & $\begin{array}{c}\text { Kerenyahan/ } \\
\text { Crispness }\end{array}$ & $\begin{array}{c}\text { Kerapuhan/ } \\
\text { Fragility }\end{array}$ & $\begin{array}{c}\text { Aroma/ } \\
\text { Odour }\end{array}$ & $\begin{array}{c}\text { Rasa/ } \\
\text { Taste }\end{array}$ & $\begin{array}{c}\text { Kecoklatan/ } \\
\text { Brownish }\end{array}$ \\
\hline A1B1 & $3.90 \pm 0.84^{\mathrm{bc}}$ & $3.73 \pm 0.63^{\mathrm{a}}$ & $3.06 \pm 1.01^{\mathrm{bc}}$ & $3.43 \pm 0.93^{\mathrm{bc}}$ & $3.50 \pm 0.86^{\mathrm{d}}$ \\
A2B1 & $3.73 \pm 0.94^{\mathrm{ab}}$ & $3.36 \pm 1.12^{\mathrm{ab}}$ & $2.90 \pm 0.92^{\mathrm{abc}}$ & $3.06 \pm 0.90^{\mathrm{b}}$ & $3.30 \pm 0.79^{\mathrm{cd}}$ \\
A3B1 & $3.60 \pm 0.67^{\mathrm{a}}$ & $3.23 \pm 0.97^{\mathrm{ab}}$ & $2.90 \pm 0.75^{\mathrm{abc}}$ & $3.30 \pm 0.98^{\mathrm{ab}}$ & $2.86 \pm 0.86^{\mathrm{c}}$ \\
A4B1 & $4.30 \pm 0.83^{\mathrm{c}}$ & $3.40 \pm 1.16^{\mathrm{ab}}$ & $2.86 \pm 0.89^{\mathrm{abc}}$ & $3.13 \pm 1.00^{\mathrm{b}}$ & $2.40 \pm 0.67^{\mathrm{b}}$ \\
A1B2 & $3.76 \pm 0.62^{\mathrm{ab}}$ & $3.43 \pm 0.97^{\mathrm{ab}}$ & $2.90 \pm 0.95^{\mathrm{abc}}$ & $3.43 \pm 0.85^{\mathrm{bc}}$ & $3.03 \pm 0.71^{\mathrm{c}}$ \\
A2B2 & $3.56 \pm 0.72^{\mathrm{a}}$ & $3.00 \pm 1.02^{\mathrm{a}}$ & $3.26 \pm 1.14^{\mathrm{c}}$ & $3.76 \pm 0.89^{\mathrm{c}}$ & $3.56 \pm 0.85^{\mathrm{d}}$ \\
A3B2 & $3.53 \pm 0.93^{\mathrm{a}}$ & $3.03 \pm 0.99^{\mathrm{a}}$ & $3.16 \pm 0.87^{\mathrm{c}}$ & $3.26 \pm 0.86^{\mathrm{bc}}$ & $2.90 \pm 0.80^{\mathrm{c}}$ \\
A4B2 & $4.16 \pm 0.69^{\mathrm{bc}}$ & $3.40 \pm 1.03^{\mathrm{ab}}$ & $2.93 \pm 1.01^{\mathrm{bc}}$ & $3.60 \pm 1.06^{\mathrm{bc}}$ & $2.93 \pm 0.82^{\mathrm{c}}$ \\
K1 & $4.06 \pm 0.73^{\mathrm{bc}}$ & $4.50 \pm 0.50^{\mathrm{c}}$ & $2.33 \pm 1.26^{\mathrm{a}}$ & $1.63 \pm 0.85^{\mathrm{a}}$ & $1.43 \pm 0.62^{\mathrm{a}}$ \\
K2 & $3.56 \pm 0.89^{\mathrm{a}}$ & $4.26 \pm 0.58^{\mathrm{c}}$ & $2.50 \pm 1.04^{\mathrm{ab}}$ & $1.73 \pm 1.11^{\mathrm{a}}$ & $1.46 \pm 0.57^{\mathrm{a}}$ \\
\hline
\end{tabular}

ditambahkan tapioka, selaras dengan penelitian Suhardi dan Haryono (2006). Warna kecoklatan kerupuk yang dihasilkan bervariasi, dipengaruhi oleh perbedaan jenis pengolahan tepung ikan dan pati. Kerupuk yang dibuat tanpa penambahan tepung ikan menghasilkan warna tidak kecoklatan. Menurut Ariyani dan Ayustaningwarno (2013), warna coklat yang terdapat pada kerupuk dipengaruhi oleh reaksi browning non enzimatis (Maillard). Reaksi Maillard terjadi antara asam amino lisin dari ikan dengan glukosa pada suhu tinggi, yang menghasilkan melanoidin berwarna coklat. Sementara itu, aroma kerupuk tanpa tambahan tepung ikan tidak menarik. $\mathrm{Hal}$ ini terlihat dengan rendahnya penilaian untuk K1 dan K2. Menurut Estiasih \& Ahmadi (2009), reaksi browning enzimatik maupun non enzimatik dapat menghasilkan aroma yang kuat.

Secara umum, nilai rata-rata rasa kerupuk adalah 1,63-3,76. Nilai rata-rata terendah memiliki kriteria rasa sangat tidak terasa ikan dan nilai tertinggi mempunyai karakteristik agak terasa ikan. Penambahan tepung ikan berpengaruh nyata terhadap rasa kerupuk. Rasa dan penerimaan konsumen terhadap suatu produk dapat dipengaruhi oleh beberapa faktor, diantaranya suhu, senyawa kimia, interaksi dengan komponen lain, dan konsentrasi. Menurut Suryani (2007), munculnya rasa dari suatu bahan pangan berasal dari bahan itu sendiri dan adanya penambahan suatu bahan saat pengolahan. Norhayani dan Aryani (2011) menyebutkan bahwa komponen yang membentuk suatu rasa bahan pangan dapat terkait dengan kandungan protein, yang menyebabkan rasa gurih dalam bahan pangan. Hasil uji organoleptik ini selaras dengan pengujian kimia fisika, yaitu A1B1 menjadi perlakuan yang terbaik untuk membuat kerupung ikan C. chanos.

\section{KESIMPULAN}

Pembuatan kerupuk ikan C. chanos yang optimal adalah dengan campuran tapioka dan tepung ikan dengan proses kukus. Kerupuk ini menghasilkan kadar air 7,01\%; daya kembang $48,41 \%$; dan elastisitas 2,43 $\mathrm{mm}$. Selain itu, karakteristik organoleptik deskriptif (skala 1-5) memperlihatkan bahwa kerupuk dengan perlakuan tersebut memiliki nilai rasa sebesar 3,43 dan agak beraroma ikan.

\section{DAFTAR PUSTAKA}

Association of Official Analytical Chemist (AOAC). (2012). Official Method of Analysis of Official Analytical of 
Chemist. The Association of Official Analytical Chemist, Inc. Arlington, Virginia.

Anggit, P., Darmanto Y.S., \& Swastawati, F. (2010). Analisis Mutu Satsuma Age Ikan Kurisi (Nemipterus sp.) dengan Penggunaan Jenis Tepung yang Berbeda. Jurnal Saintek Perikanan, 6(2), 13-22.

Anjar, T. P., Dwi, I., \& Dimas, R. A. M. (2013). Kajian Karakteristik Fisikokimia Tepung Labu Kuning (Cucurbita moschata) Termodifikasi Dengan Variasi Lama Perendaman dan Konsentrasi Asam Asetat. Jurnal Teknosains Pangan, 2(2), 2013.

Ariyani, M., \& Ayustaningwarno, F. (2013). Pengaruh Penambahan Tepung Duri Ikan Lele Dumbo (Clarias gariepinus) dan Bubur Rumput Laut (Eucheuma cottonii) Terhadap Kadar Kalsium, Kadar Serat Kasar dan Kesukaan Kerupuk. Journal of Nutrition College 2(1), 223-231. doi: 10.14710/jnc.v2i1.2121

Assadad, L., Hakim, A. R \& Widianto, T. N. (2015). Mutu Tepung Ikan Rucah pada Berbagai Proses Pengolahan. Seminar Nasional Tahunan XII Hasil Penelitian dan Kelautan, PP. 02: 53-62.

Astuti, S., Suharyon., \& Fitria, N. (2016). Pengaruh Formulasi Jamur Tiram Putih (Pleurotus oestreatus) dan Tapioka Terhadap Sifat Fisik, Organoleptik, dan Kimia Kerupuk. Jurnal Penelitian Pertanian Terapan, 16(3),163-173. doi: 10.25181/jppt.v16i3.94

Aziz A. F., Nematollahi, A., Siavash, \& Saei - Dehkordi, S. (2013). Proximate Composition and Fatty Acid Profile of Edible Tissues of Capoeta damascina (Valenciennes, 1842) reared in freshwater and brack ish water. Journal of Food Composition and Analysis, 32, 150 -154. doi: 10.1016/j.jfca.2013.09.004

Badan Standardisasi Nasional (BSN). (2006). Petunjuk Pengujian Organileptik dan/atau Sensori. SNI 01.2346-2006. Jakarta: Badan Standardisasi Nasional.

Badan Standardisasi Nasional (BSN). (2009). Standar Nasional Indonesia Persyaratan Mutu dan Keamanan Pangan Kerupuk Ikan. SNI 2713-1-2009. Jakarta: Badan Standardisasi Nasional.

Damayanti, D. A., Wahyuni, W., \& Wena M. (2014). Kajian Kadar Serat, Kalsium, Protein dan Sifat Organoleptik Chiffon Cake Berbahan Mocaf Sebagai Alternatif Pengganti Terigu. Jurnal Teknologi dan Kejuruan, 37(1), 73-82. doi: 10.17977/tk.v37i1.4109

Estiasih, T. \& Ahmadi, Kgs. (2009). Teknologi Pengolahan Pangan. Jakarta: Sinar Grafika.

Faridah, A, Pada, S.P., Yulastri, A., \& Yusuf, L., (2018). Patiseri Jilid 3. Direktorat Pembinaan Sekolah Menengah Kejuruan. Jakarta. 402-445.

Hafiludin. (2015). Analisis Kandungan Gizi Pada Ikan Bandeng Yang Berasal Dari Habitat Yang Berbeda. Jurnal Kelautan, 8(1). doi: 10.21107/jk.v8i1.811

Hayati, R., Abdullah, A., Ayob, M. K., \& Soekarto, S.T. (2004). Isotermi Sorpsi Air dan Analisis Umur Simpan Ikan Kayu Tongkol dari Aceh. Jurnal Teknologi dan Industri Pangan, 15 (3), 207-213.

Kusumaningrum, I. (2009). Analisa Faktor Daya Kembang dan Daya Serap Kerupuk Rumput Laut
Pada Variasi Proporsi Rumput Laut (Eucheuma cottonii). Jurnal Teknologi Pertanian, 4(2), 63-68.

Nadeem, M. A. (2003). Production and Quality of Fish in Pakistan. Anim Nutri Conf. Pakistan. University Vet. Anim Sci.

Norhayani \& Aryani. (2011). Pengaruh Konsentrasi Putih Telur Ayam Ras Terhadap Kemekaran Kerupuk Ikan Mas (Cyprinus carpio). Journal of Tropical Fisheries, 6(2), 593-596.

Nurchotimah. (2002). Pemanfaatan Daging-Tulang Leher Ayam Sebagai Bahan Baku Tambahan Kerupuk. Skripsi. Teknologi Hasil Ternak. Institut Pertanian Bogor. Bogor.

Nurhayati, A. (2007). Sifat Kimia Kerupuk Goreng yang Diberi Penambahan Tepung Daging Sapi dan Perubahan Bilangan TBA Selama Penyimpanan. Skripsi. Teknologi Hasil Ternak. Institut Pertanian Bogor. Bogor.

Rizqia, F. N. (2016). Karakterstik Kerupuk Ikan dari Jenis Ikan dan Jenis Pati yang Berbeda. Skripsi. Teknologi Pangan. Universitas Pasundan. Bandung.

Rosiani, N., Basito., \& Widiowati, E. (2015). Kajian Karakteristik Sensoris Fisik dan Kimia Kerupuk Fortifikasi Daging Lidah Buaya (Aloe vera) Dengan Metode Pemanggangan Menggunakan Microwave. Jurnal Hasil Pertanian, 8(2), 84-98.

Saraswati, A. (2013). Efek Pengukusan Terhadap Kandungan Asam Lemak dan Kolestrol Kakap Merah (Lutjanus bohar). Skripsi. Dapertemen Teknologi Hasil Perairan Fakultas Perikanan dan IImu Kelautan. Institut Pertanian Bogor. Bogor.

Sirpatrawan, U. (2009). Shelf-life simulation of packaged rice crackers. Journal of Food Quality 32(2), 224-239.

Suhardi, S., \& Haryono, B. (2006). Prosedur Analisis Untuk Makanan dan Pertanian. Lyberty: Yogyakarta.

Suryani, D. A. L. (2007). Kualitas Kerupuk Rambaak Kulit Kambing Peranakan Etawah (PE) dan Peranakan Boer (PB) Ditinjau dari Kadar Air, Daya Kembang, Rasa dan Kerenyahan. Skripsi. Fakultas Peternakan. Universitas Brawijaya. Malang.

Susanto, A., \& Nurhikmat, A. (2008). Pengaruh proses Perebusan, Pengukusan dan Pengepresan terhadap Kualitas Tepung Ikan. Prosiding Seminar Nasional Tahunan V Hasil Penelitian Perikanan dan Kelautan, 05,1-7.

Wahyuningtyas, N. B., \& Atmaka, W. (2014). Kajian Karakteristik Fisikokimia dan Sensoris Kerupuk Berbahan Baku Tepung Terigu, Tepung Tapioka dan Tepung Pisang Kepok Kuning. Jurnal Teknosains Pangan, 3(2), 76-85.

Witono, J. R., Kumalaputri., A. J., \& Lukman., H. S. (2012). Optimasi Rasio Tepung Terigu, Tepung Pisang, dan Tepung Ubi Jalar, Serta Konsentrasi Zat Aditif Pada Pembuatan Mie. Skripsi. Lembaga Penelitian dan Pengabdian Kepada Masyarakat. Universitas Katolik Parahayangan.

Yuliani., Marwati., Wardana, H., Emmawati, A., \& Candra, K. P. (2018). Karakteristik Kerupuk Ikan dengan Substitusi Tepung Tulang Ikan Gabus (Channa 
striata) Sebagai Fortifikasi Kalsium. JPHPI, 21(2). doi: 10.17844/jphpi.v21i2.23042

Zulfahmi, A. N., Swastawati, F., \& Romadhon. (2014). Pemanfaatan Daging ikan Tenggiri (Scomberomorus commersoni) dengan Konsentrasi yang Berbeda pada Pembuatan Kerupuk Ikan. Jurnal Pengolahan dan Bioteknologi Hasil Perikanan 3(4), 133-139. 